\title{
AIR BRUSH TECHNOLOGY, WEBSITE BRANDING AND CASH FLOW MANAGEMENT IN J-ART MEDAN
}

\author{
Roza Thohiri $^{*}$, Khairunisa Harahap ${ }^{2}$, Bagoes Maulana ${ }^{3}$, Andri Zainal ${ }^{4}$, Pasca Dwi Putra ${ }^{5}$ \\ ${ }^{1}$ Department of Economic Education, Faculty of Economics, Universitas Negeri Medan, Medan, Indonesia \\ ${ }^{2}$ Department of Accounting, Faculty of Economics, Universitas Negeri Medan, Medan, Indonesia \\ ${ }^{3}$ Department of Electrical Engineering Education, Faculty of Engineering, Universitas Negeri Medan, Medan, \\ Indonesia \\ ${ }^{4}$ Department of Accounting Education, Faculty of Economics, Universitas Negeri Medan, Medan, Indonesia \\ ${ }^{5}$ Department of Business Education, Faculty of Economics, Universitas Negeri Medan, Medan, Indonesia \\ * Correspondent Author: rozatho@unimed.ac.id
}

\begin{abstract}
This dedication activity is focused on solving the problems that become priority problems, namely the lack of application of appropriate technology tools that can accelerate the process of coloring art products, and good and standardized management and financial strategies and website creation. The partners involved in this activity are J-Art SMEs led by Mr. Faisal Walad. This UMKM is located at Jalan Umar Gg. Karsidi No.70, Glugur Darat I Village, Medan Timur District. The service activities referred to are the provision and assistance of the use of wind compressor machines and spray guns, good management assistance and assistance of manual and electronic financial reports and the provision of website branding. This activity also resulted in several outcomes in the form of TTG implementation, management and financial assistance and a commercial website.
\end{abstract}

Keywords: Air Brush; Management; Finance; Website.

\section{INTRODUCTION}

Until now, the problem of waste remains a major problem in urban communities. At this time it is estimated that the number of landfills has reached almost 1,421 tons / day in Medan and if it is not responded immediately, this will certainly have a negative impact on the environment. In an effort to reduce the volume of rubbish heaps in Medan, it is expected that the active role of the community in efforts to reduce rubbish by carrying out the $3 \mathrm{R}$ (Reuse, Reduce and Recycle) approach is one of the solutions in protecting the environment that is cheap and easy to do.

The assumption that waste is a source of problems must be changed, because it can be an additional source of income for people who have expertise, by turning it into economic value goods. One of them is newspaper waste paper. Newspaper is always produced and consumed by readers every day, this causes a huge volume of waste. Whereas based on research and some experience in the field, newspaper waste is a potential material to be used as a variety of recycled products that have artistic value.

The plastic waste processing business is far more developed than the paper waste business, for that the potential is huge to be developed. In the Salam Rancage home industry, Jalan Al-Hasanah Tanah Baru, Bogor City, West Java, this business has been highly developed. Craftsmen weave used newspaper waste materials for making perfume bottle boxes and various crafts such as mats, laundry boxes, pencil holders, tissue boxes, fruit containers and various other household items for export orders to a number of countries such as Italy, Denmark and the United States.

In the city of Medan, this business has begun to be developed by Mr. Faisal Walad. About 3 years ago, starting from seeing the learning given by the teacher of creativity that teaches young children about the use of newsprint, Mr. Faisal Walad was challenged to start trying to learn to use newspaper to become a valuable work of art. In addition to utilizing newsprint, it also utilizes coconut shells, wood, bamboo and used paralones. After being taken seriously, Mr. Faisal then established the UMKM under the name J-Art, which is actively developing several products from used newspapers.

Some of the products produced from the use of used newspapers are souvenirs of miniature dolls of traditional clothing in Indonesia, a variety of miniature turtle-shaped key chains, miniature people with traditional clothes, paintings made from newsprint and others, besides being beneficial in reducing newspaper waste, this miniature also preserving and preserving Indonesian culture. Until now, the sales turnover of products from J-Art ranges from Rp. 3,500,000.00 to Rp. 5,000,000.00 each month where the largest portion of sales turnover is generated from miniature custom clothing. 
Every month, partners are able to produce as many as 20-50 sets of miniature custom clothing, 50-100 key chains and fridge magnets, and 1-2 wall paintings. Price ranges for miniature custom clothing ranging from Rp.250,000, Rp.600,000, key chains and magnets starting from Rp.5,000, - Rp.10,000, and paintings starting from Rp. 200,000 Rp.500,000. Some of the products made by partners can be seen in the picture below.
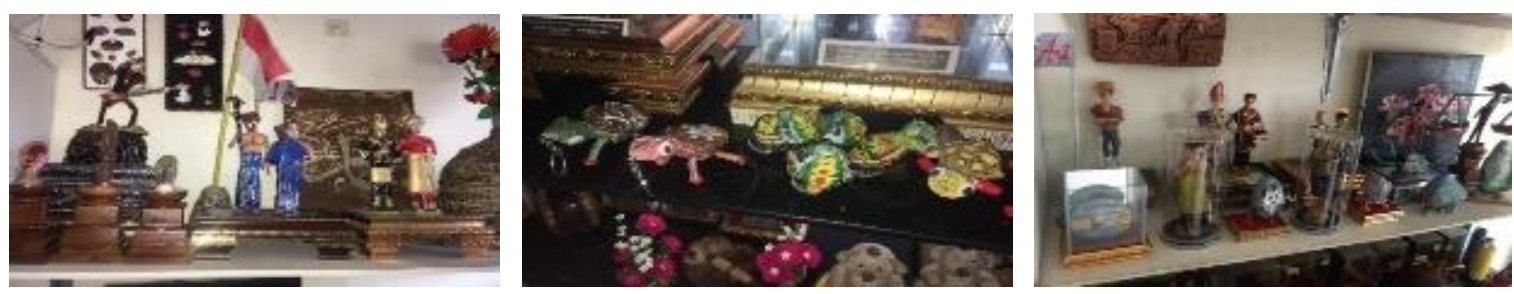

Figure 1. Products Produced by Partners.

There are several challenges and obstacles experienced by partners, the first is in the production phase. For the coloring process, so far still using bottled paint which results are not optimal, high costs and the risk of damaged products becomes large because they have to be careful in spraying, resulting in the duration of the production process and limited production. To overcome the problems of production partners need appropriate technology tools (ATTGs) in the form of compressor and spray gun machines.

The challenges and obstacles experienced by the second partner are from management and finance. Partner management still consists of 2 (two) production and arts workers and is assisted by one person who oversees bookkeeping, so it is still not well-organized division of tasks and responsibilities of each member in the organization, even though demand is quite high so sometimes the division of tasks in production can't go well. From the financial side, financial arrangements are still managed by Mr. Faisal's wife, so that sometimes there is a mix of personal, household and income from other businesses such as child care and boutiques which are the businesses of Mr. Faisal's wife. The financial records that have not followed the generally accepted financial standardization, so that partners cannot report the actual financial position, this also makes the addition of capital assets insignificant, even though the monthly turnover is quite good. Assistance in the management of manual and electronic financial management and reporting is expected to be able to overcome the problems of partners.

The challenge and obstacle experienced by the third partner is branding. Marketing is now quite good, because it often follows exhibitions conducted and uses social media such as Instagram and Facebook. However, in the social media platform, product marketing partners tend to be limited in terms of the quality and quantity of displays and product information as well as customer service flexibility and product content that is not up to date. On the other hand, the character of art products that emphasize more aesthetic aspects requires more diverse and multi-dimensional promotional spaces for optimizing product introduction to a wider market segment with demands for more personalized product creation. Updating product information and partnerships with online buying and selling sites and creating a website-based platform can help partners improve their product branding.

This community service activity involves 1 (one) partner, namely MSME J-Art led by Mr. Faisal Walad. This UMKM is located at Jalan Umar Gg. Karsidi No.70, Glugur Darat I Village, Medan Timur District. In his daily production and marketing activities, Mr. Faisal Walad was only assisted by his wife and one member of the production. J-Art UMKM has been operating since 2017 and has obtained a permit from the North Sumatra Provincial Government. So far, he often participates in exhibitions held by both the government and the private sector. The use of social media as a primary promotional tool by partners is still dominated by photo content and prices. However, Instragram (@ j.art_medan) and Facebook (J Art) accounts managed by partners do not yet contain a professional business profile. The solution to solve this problem in service is outlined in the table below:

Table 1. Matrix of Priority Problems and Alternative Solutions.

\begin{tabular}{llll}
\hline No & \multicolumn{1}{c}{ Priority Issues } & \multicolumn{1}{c}{ Alternative Solutions } \\
\hline $\mathbf{1}$ & $\begin{array}{l}\text { The absence of the application of } \\
\text { appropriate technology tools (ATTGs) } \\
\text { that are able to accelerate the coloring } \\
\text { process of art products. }\end{array}$ & $\begin{array}{l}\text { Utilization and assistance in the use of wind compressor and spray } \\
\text { follows:- Horse power } 1 / 4 \text { HP- Cylinder 1, tank 36 L- Dimensions } \\
775 \times 290 \times 605 \text { mm- Trans Magneto Ignition System }\end{array}$ \\
\hline $\mathbf{2}$ & $\begin{array}{l}\text { Good and standardized management and } \\
\text { financial strategies and website } \\
\text { branding }\end{array}$ & $\begin{array}{l}\text { Mentoring management and financial reports manually and } \\
\text { electronically as well as creating a commercial website. }\end{array}$ \\
\hline
\end{tabular}

\section{MATERIALS AND METHODS OF IMPLEMENTATION}


The proposed activity includes 3 (three) steps of actualizing the solution to overcome the problems of partners where each stage consists of several specific steps as follows:

a) Stage Pre-Implementation Activities. In this stage, the proposing team conducts initial communication with partners to conduct site reviews, identify problems that are the basis for developing solutions and formulate and determine solutions that will be applied to partners.

b) Stage of Activity Implementation. This stage includes activities aimed at, In-depth discussion and assistance related to the application of ATTG as much as 1 (one) time activity involving 1 (one) expert resource person (machinery consultant). Doassistance related to Management and Finance SOP for 2 (two) activities involving the Proposer Team. And make a website.

c) Post-Implementation Activities. In this stage, the proposing team designs several key activities intended to, ensure the realization of the achievement of activities in accordance with the planned targets, compile a final report on the implementation of the activities and finalize the compilation of the required output targets.

Specifically, J-Art UMKM's participation led by Mr. Faisal Walad in the implementation of this activity consisted of providing information and facilities for the implementation of the program, attending and actively participating in the adoption of jointly determined solutions and following up on the intended solutions independently after implementation activities with or without further assistance from the activity implementation team. The equipment used in this service is a wind compressor and sprayer gun with the specifications in the table below:

Table 2. Equipment Specifications.

\begin{tabular}{llc}
\hline \multicolumn{1}{c}{ Air Compressor Specifications } & \multicolumn{1}{c}{ Sprayer Gun Specifications } \\
\hline Compressor Power: 1/4 HP & Model & $:$ K-350 \\
Number of Cylinders: 1 & Material & : Aluminum Alloy \\
Working Pressure (Bar): 8 BAR & Color & $:$ Brown \\
Air Delivery Compressor: 1.59 CFM & Feed Type & $:$ Gravity \\
Air Delivery Compressor: 45 L / Min & Technology & $: 0.8 \mathrm{~mm}$ \\
Oilless: No.Compressor & Nozzle caliber(mm) & $: 1 / 4 \mathrm{BSP}$ \\
Type: Belt Driven & Air inlet(BSP) & $: 36.3 \mathrm{psi}$ \\
Tube Volume: $36 \mathrm{~L}$ & Painting pressure(psi) & $: 20 \mathrm{~cm}$ \\
Tank Position: Horizontal & Painting distance(cm) & $: 10 \mathrm{~cm}$ \\
Electric Motor Power: $1 / 4$ HP 1P & Painting width(cm) & $: 4.41 \mathrm{oz}$ \\
Input Voltage: $220 \mathrm{~V}$ & Aluminium pot capacity(oz) & $: 1.0-2.0 \mathrm{cfm}$ \\
mensions (LxWxH): 775 x 290 x 605Net & Air consumption(cfm) & \\
Weight: 26 KG & & \\
\hline
\end{tabular}

\section{RESULTS AND DISCUSSION}

Overall Community Service Activities were carried out from 15 May 2019 to 10 November 2019. Most of the activities were carried out by correspondence and consultation with the communication media. Meanwhile formal activities and direct interaction remain the main agenda in this community service activity. Various face-to-face activities and the implementation of the training were held in August and September. Implementation and implementation of activities that have taken place are as follows:

1) Implementation of activities is observation to identify initial situations. Method of approach Conduct field observations and interviews with partners. Partner participation is preparing data for in-depth interviews and meeting rooms.

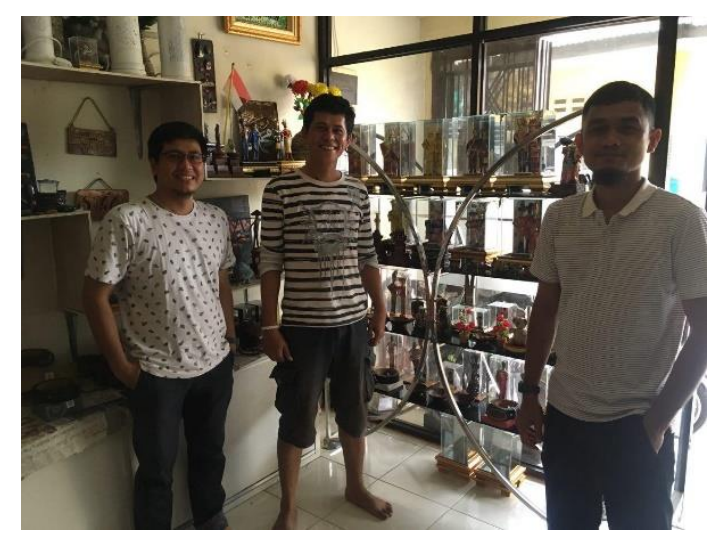


Figure 2. Initial Observation Activities.

2) Implementation of activities is the formulation of problems. Internal FGD approach method among the proposing team; and then offered to partners. Partner participation is to provide feedback regarding solutions offered, be cooperative, and reach a solution agreement with the proposing team.

3) Implementation of activities is the provision of good management assistance and standardized financial assistance. Methods of approach with Participatory, focus group discussions and consultancy. Partner participation is to provide training space, participate and play an active role during activities.

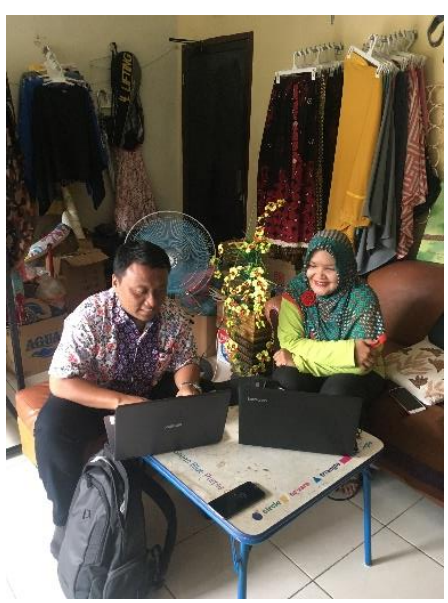

Figure 3. Management and Financial Assistance Activities.

4) Implementation of activities is the provision of ATTG wind compressor machines and spray guns. Handover approach method, ATTG engine compressor and spray gun. Partner participation is to sign the minutes of ATTG submission.

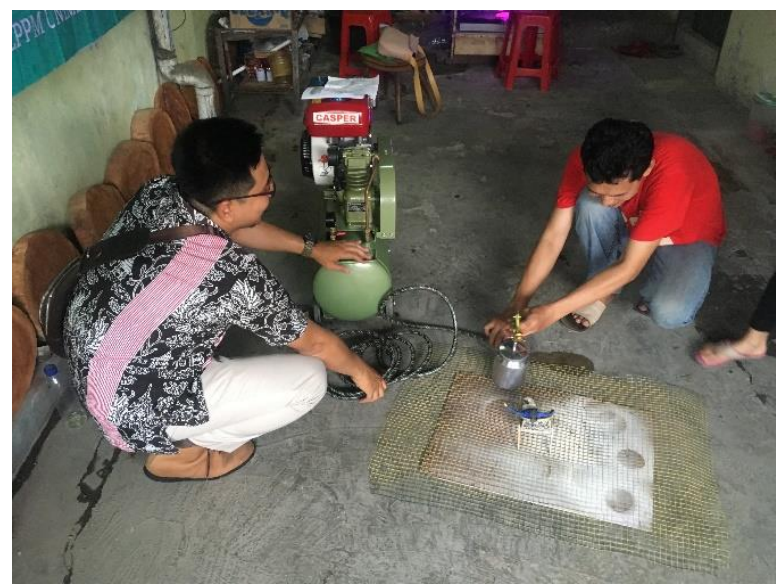

Figure 4. Provision of ATTG and Utilization Training.

5) Implementation of activities is the creation of a website with the address www.jartmedan.com. Method of handover approach and website training. Partner participation is signing the minutes of website submission, providing training space and actively participating in the training.

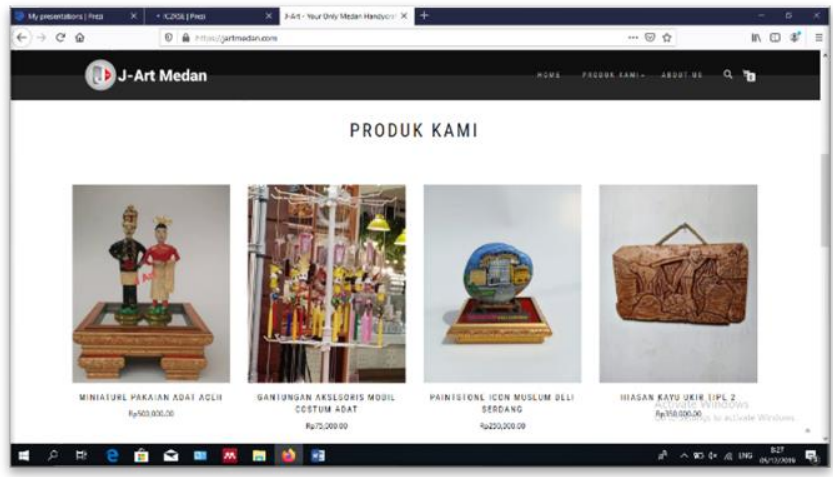


Figure 5. Commerce Website for Partners.

This activity has resulted in several outcomes that become bills on community service activities. The output can be described as follows:

1) Appropriate technology in the form of compressor machines, spray guns and hoses

2) Training in human resource management and business management

3) Training on making financial statements

4) Website at www.jartmedan.com

5) Publication in Mass Media at Medan Bisnis Daily on Thursday, September 12, 2019, and can be accessed online at medanbisnisdaily.com with the title "LPPM Unimed Accompanying the Recycling Business of Used Newspaper Paper Processing".

\section{CONCLUSION}

Based on the results of community service activities to J-Art SMEs and the results of the assistance that has been done, the conclusions and suggestions given are as follows:

1) UMKM J-Art has used TTG Air Brush with a compressor engine, spray gun and hose in painting its products for efficiency and effectiveness in time and cost.

2) MSME J-Art has made changes in governance in the production process and human resources.

3) MSME J-Art has made financial records and financial reporting in accordance with financial accounting standards

4) MSME J-Art has a website that can be used to introduce and market its products regionally and internationally with the address www.jartmedan.com.

5) Stakeholders (Scientists, Academics, Practitioners, Government) must be able to appreciate the MSME initiatives. Furthermore, the appreciation should be able to transform into giving direct and indirect attention and roles that can support the financial and non-financial performance of J-Art MSMEs in particular and other MSMEs in general, so as to achieve its main goal of improving the people's economy.

6) Suggestions for proposing community service grants in the Community Partnership Program scheme from the Ministry of Research and Technology, because they provide opportunities for the implementation of more flexible activities from a budgetary perspective and this will support the achievement of more concrete goals.

7) In the next service activity, assistance is needed regarding design patents on products produced and technology in rolling and cutting newsprint.

8) To increase productivity and income, J-Art needs to develop a more comprehensive website.

\section{ACKNOWLEDGEMENT}

Thank you to Medan State University, LPPM Unimed, Faculty of Economics, Faculty of Engineering, J-Art Medan, Kelurahan Glugur Darat I and all those who have helped to carry out this service program.

\section{REFERENCES}

http://medan.tribunnews.com/2018/11/22/ubah-perilaku-pengelolaan-sampah-demi-wujudkan-medan-zero-wastecity-2020?page=all di akses tanggal 6 Agustus 2019.

http://www.medanbisnisdaily.com/news/read/?id=269245 di akses tanggal 6 Agustus 2019.

http://www.medanbisnisdaily.com/news/online/read/2019/09/12/86291/lppm_unimed_dampingi_usaha_daur_ulang _pengolahan_kertas_koran_bekas/ di akses tanggal 1 Oktober 2019 